\title{
Integrated Reading and Composition (CIRC) Type in Improving Intensive Reading Skills of Grade III SD N 7 Kutosari in Academic Year 2018/2019
}

\author{
Ayu Setiya Munika1, Suhartono ${ }^{2}$, Tri Saptuti Susiani ${ }^{3}$ \\ 1,2,3Universitas Sebelas Maret \\ ayusetiya01@gmail.com
}

\section{Article History}

accepted 01/06/2019

published 01/08/2019

\begin{abstract}
This study aimed to describe the steps for implementing the cooperative learning type CIRC model and improve intensive reading skills of students through the application of the CIRC type of cooperative learning model. This research is a collaborative Classroom Action Research (CAR) carried out in three cycles. The data used were quantitative data and qualitative data. Data collection techniques used observation, interviews, and tests. Data validity used technique triangulation and sources. Data analysis included data reduction, data presentation, and drawing conclusion. Data collection techniques used were observation, interviews, and tests. The results showed that the application of the CIRC type cooperative learning model was carried out with seven steps, namely: (1) orientation, (2) heterogeneous group formation, (3) reading division in accordance with the topics to be discussed, (4) group discussions, (5) reading the results of the discussion, (6) conclusion, and (7) closing. The application of the CIRC learning model carried out with these steps could improve students' intensive reading skills through the increase on the percentage of students' completeness by $63.63 \%$ in the first cycle, $75.00 \%$ in the second cycle, and $86.37 \%$ in the third cycle.
\end{abstract}

Keywords: CIRC model, intensive reading

\section{Abstrak}

Penelitian ini bertujuan untuk menggambarkan langkah-langkah untuk menerapkan model pembelajaran kooperatif tipe CIRC dan meningkatkan keterampilan membaca intensif siswa melalui penerapan model pembelajaran kooperatif tipe CIRC. Penelitian ini merupakan Penelitian Tindakan Kelas kolaboratif (PTK) yang dilaksanakan dalam tiga siklus. Data yang digunakan adalah data kuantitatif dan data kualitatif. Teknik pengumpulan data menggunakan observasi, wawancara, dan tes. Validitas data menggunakan teknik triangulasi dan sumber. Analisis data meliputi reduksi data, penyajian data, dan penarikan kesimpulan. Teknik pengumpulan data yang digunakan adalah observasi, wawancara, dan tes. Hasil penelitian menunjukkan bahwa penerapan model pembelajaran kooperatif tipe CIRC dilakukan dengan tujuh langkah, yaitu: (1) orientasi, (2) pembentukan kelompok heterogen, (3) pembagian bacaan sesuai dengan topik yang akan dibahas, (4) diskusi kelompok, (5) membaca hasil diskusi, (6) kesimpulan, dan (7) penutupan. Penerapan model pembelajaran CIRC yang dilakukan dengan langkah-langkah ini dapat meningkatkan keterampilan membaca intensif siswa melalui peningkatan persentase ketuntasan siswa sebesar $63,63 \%$ pada siklus pertama, $75,00 \%$ pada siklus kedua, dan $86,37 \%$ pada siklus ketiga. siklus.

Kata kunci: model CIRC, membaca intensif 


\section{PENDAHULUAN}

Salah satu pengajaran dan pelatihan yang penting bagi manusia adalah keterampilan berbahasa. Fungsi bahasa yang utama adalah sebagai alat komunikasi. Menurut Susanto (2016: 242) penggunaan bahasa dalam komunikasi dapat dibedakan menjadi dua hal, yaitu lisan dan tulisan. Agar seseorang dapat menggunakan bahasa dalam sebuah komunikasi, maka ia harus memiliki kemampuan berbahasa yang bisa didapat melalui pembelajaran Bahasa Indonesia.

Pembelajaran Bahasa Indonesia, terutama di sekolah dasar tidak dapat terlepas dari empat keterampilan berbahasa yaitu, keterampilan menyimak atau mendengarkan (listening skills), keterampilan berbicara (speaking skills), keterampilan membaca (reading skills), dan keterampilan menulis (writing skills). Keempat keterampilan berbahasa ini saling berkaitan satu dengan lainnya (Susanto, 2016: 241).

Keberhasilan pembelajaran Bahasa Indonesia pada jenjang sekolah dasar, perlu adanya beberapa elemen yang saling terkait satu dengan lainnya yaitu kepala sekolah, guru, dan siswa. Dari elemen-elemen tersebut, yang berperan besar dalam proses pembelajaran adalah guru. Salah satu cara yang dapat membantu guru dalam proses pembelajaran adalah dengan menggunakan model pembelajaran yang dapat memancing siswa untuk aktif sehingga kegiatan pembelajaran akan semakin bermakna, namun tentu saja model pembelajaran yang diterapkan harus sesuai dengan karakteristik siswa sekolah dasar yang cenderung aktif dan menyenangkan.

Berdasarkan observasi yang dilakukan di kelas III SD Negeri 7 Kutosari ditemukan 3 fakta yang menunjukkan bahwa pembelajaran Bahasa Indonesia di kelas tersebut belum sesuai dengan yang diharapkan. Pertama, guru jarang menggunakan model pembelajaran yang inovatif dan variatif. Kedua, siswa jarang dilibatkan pada kegiatan pembelajaran yang aktif. Ketiga, masih cukup banyak siswa yang mengalami kesulitan pada mata pelajaran Bahasa Indonesia khususnya pemecahan masalah yang berkaitan dengan keterampilan berbicara, membaca dan menulis.

Diketahui bahwa menurut Brooks (1964) yang dimaksud dengan membaca intensif atau intensive reading adalah sebuah studi seksama, telaah teliti, dan penanganan terperinci terhadap suatu tugas yang pendek kira-kira dua sampai empat halaman setiap hari. Kuisioner, latihan pola-pola kalimat, latihan kosa kata, telaah kata, dikte, dan diskusi umum merupakan bagian dan teknik dari membaca intensif (Tarigan, 2008: 36-37).

Dari pemaparan tersebut, peneliti berupaya untuk melakukan perbaikan dalam proses pembelajaran utamanya pada penggunaan model pembelajaran yang memancing siswa untuk aktif dan bisa meningkatkan keteramilan membaca intensif siswa.. Salah satu model pembelajaran yang menuntut siswa untuk aktif yaitu model pembelajaran kooperatif. Dalam penelitian ini, peneliti tertarik menggunakan model pembelajaran kooperatif tipe CIRC (Cooperative Integrated Reading and Composition). CIRC merupakan komposisi terpadu membaca dan menuli s secara berkelompok. Model CIRC merupakan model pembelajaran khusus pelajaran bahasa dalam membaca dan menemukan ide pokok atau tema sebuah wacana (Shoimin, 2014: 51). Selanjutnya, Huda (2015: 221) mengemukakan bahwa model pembelajaran kooperatif tipe CIRC merupakan model terpadu untuk mengajarkan membaca dan menulis siswa di sekolah dengan cara siswa ditugaskan untuk belajar tim atau kelompok dengan serangkaian kegiatan di mana setiap anggota kelompok saling mengeluarkan ide-ide untuk memahami suatu konsep dan menyelesaikan tugas, sehingga terbentuk pemahaman dan pengalaman belajar yang lama.

Berdasarkan pendapat di atas, peneliti tertarik untuk melakukan Penelitian Tindakan Kelas (PTK) Kolaboratif dengan judul "Penerapan Model Pembelajaran Kooperatif Tipe Cooperative Integrated Reading and Composition (CIRC) Dalam Peningkatan Keterampilan Membaca Intensif Pada Siswa Kelas III SD N 7 Kutosari 
Tahun Ajaran 2018/2019". Diharapkan dengan penelitian ini dapat meningkatkan keterampilan membaca intensif siswa dalam pembelajaran Bahasa Indonesia.

Berdasarkan uraian di atas, maka dapat dirumuskan masalah yang muncul yaitu: (1) bagaimakah langkah-langkah penerapan model pembelajaran kooperatif tipe CIRC? dan (2) apakah penerapan model pembelajaran kooperatif tipe CIRC dapat meningkatkan keterampilan membaca intensif pada siswa kelas III SD N 7 Kutosari tahun ajaran 2018/2019?

Penelitian ini bertujuan untuk: (1) mendeskripsikan langkah-langkah penerapan model pembelajaran kooperatif tipe CIRC dan (2) meningkatkan keterampilan membaca intensif melalui penerapan model pembelajaran kooperatif tipe CIRC pada siswa kelas III SD N 7 Kutosari tahun ajaran 2018/2019.

\section{METODE}

Penelitian ini merupakan penelitian tindakan kelas (PTK) kolaboratif yang dilaksanakan dalam tiga siklus. Penelitian ini menggunakan prosedur penelitian modifikasi dari Arikunto, Suhardjono \& Supardi (2014: 16) yang setiap siklusnya terdiri dari tahap perencanaan, pelaksanaan, pengamatan, dan refleksi.Setiap siklus terdiri dari empat tahap yaitu: perencanaan, pelaksanaan, pengamatan, dan refleksi. Subjek dalam penelitian ini adalah siswa kelas III SD N 7 Kutosari yang berjumlah 22 siswa.

Data yang digunakan adalah data kuantitatif berupa nilai evaluasi keterampilan membaca intensif dan data kualitatif berupa hasil observasi dan wawancara. Teknik pengumpulan data menggunakan observasi, wawancara, dan tes. Validitas data menggunakan triangulasi teknik dan sumber. Analisis data meliputi reduksi data, penyajian data, dan penarikan kesimpulan. Indikator kinerja penelitian ini adalah peningkatan keterampilan membaca intensif siswa dengan target $85 \%$ dan ketuntasan minimal siswa dengan target $80 \%$.

\section{HASIL DAN PEMBAHASAN}

Penelitian ini dilaksanakan selama tiga siklus dengan menerapkan tujuh langkah model pembelajaran CIRC yaitu: (1) orientasi, orientasi, (2) pembentukan kelompok secara heterogen, (3) pembagian bacaan sesuai dengan topik yang akan dibahas, (4) diskusi kelompok, (5) pembacaan hasil diskusi, (6) kesimpulan, dan (7) penutup. Langkah-langkah tersebut sesuai dengan teori menurut Huda (2015: 222) dan menurut Amri (2013: 17).

Hasil pengamatan terhadap pelaksanaan pembelajaran bahasa Indonesia dengan menerapkan model pembelajaran kooperatif tipe CIRC mengalami peningkatan pada setiap siklusnya. Hasil pengamatan dapat dapat dilihat pada tabel 1 di bawah ini:

Tabel 1. Persentase Hasil Pengamatan Penerapan Model Pembelajaran CIRC

\begin{tabular}{llll}
\hline Sumber & \multicolumn{2}{l}{ Siklus } & \\
\cline { 2 - 4 } Data & $\mathbf{I}$ & $\mathbf{I I}$ & $\mathbf{I I I}$ \\
\hline Guru (\%) & 77,57 & 84,69 & 91,58 \\
Siswa (\%) & 73,54 & 80,59 & 88,05 \\
\hline
\end{tabular}

Hasil pengamatan terhadap guru pada siklus I ke siklus II meningkat sebesar $7,12 \%$ dari $77,57 \%$, menjadi $84,69 \%$, dan pada siklus II ke siklus III meningkat sebesar $6,89 \%$ dari $84,69 \%$ menjadi $91,58 \%$. Persentase rata-rata hasil pengamatan kepada siswa juga mengalami peningkatan pada siklus I ke siklus II sebesar 7,05\% yaitu dari $73,54 \%$ menjadi $80,59 \%$ dan pada siklus II ke siklus III meningkat sebesar $7,46 \%$ dari $80,59 \%$ menjadi $88,05 \%$. 
Hasil keterampilan membaca intensif didapat dari hasil evaluasi yang dilakukan pada akhir pembelajaran setiap pertemuan. Analisis didapat berdasarkan jumlah persentase ketuntasan siswa. Berikut adalah hasil belajar siswa pada siklus I, II, dan III:

Tabel 2. Analisis Hasil Keterampilan Membaca Intensif Siswa

\begin{tabular}{ll}
\hline Siklus & $\begin{array}{l}\text { Persentase } \\
\text { Ketuntasan Siswa }\end{array}$ \\
\hline Siklus I & $63,63 \%$ \\
Siklus II & $75,00 \%$ \\
Slklus III & $86,37 \%$ \\
\hline
\end{tabular}

Berdasarkan data di atas, dapat diketahui bahwa persentase ketuntasan siswa pada siklus I ke siklus II meningkat sebesar $11,37 \%$ dari $63,63 \%$ menjadi $75,00 \%$ dan dari siklus II ke siklus III meningkat sebesar $11,37 \%$ dari $75,00 \%$ menjadi $86,67 \%$.

Berdasarkan tabel 1 dapat disimpulkan bahwa penerapan model pembelajaran CIRC sudah dilaksanakan dengan baik dan sudah mencapai target indikator kinerja penelitian sebesar $85 \%$. Selanjutnya, berdasarkan tabel 2 dapat disimpulkan bahwa ketuntasan minimal siswa sudah mencapai target indikator kinerja penelitian sebesar $80 \%$ dan meningkat di setiap siklusnya.

Hal tersebut sesuai dengan penelitian yang dilakukan Sutirto (2016) yang telah membuktikan bahwa penerapan model CIRC dapat meningkatkan keterampilan berbahasa siswa sekolah dasar terutama keterampilan membaca.

\section{SIMPULAN}

Berdasarkan hasil penelitian dan pembahasan yang telah diuraikan, maka dapat disimpulkan bahwa: (1) penerapan model pembelajaran kooperatif tipe CIRC dilakukan dengan tujuh langkah yaitu: (a) orientasi, (b) pembentukan kelompok secara heterogen, (c) pembagian bacaan sesuai dengan topik yang akan dibahas, (d) diskusi kelompok, (e) pembacaan hasil diskusi, (f) kesimpulan, dan (g) penutup; dan (2) penerapan model pembelajaran kooperatif tipe CIRC dapat meningkatkan keterampilan membaca intensif yang dilihat dari kenaikan persentase ketuntasan minimal siswa yaitu pada siklus I sebesar $63,63 \%$, pada siklus II meningkat menjadi $75,00 \%$, dan pada siklus III meningkat menjadi $86,37 \%$.

\section{DAFTAR PUSTAKA}

Arikunto, S., Suhardjono, \& Supardi. (2014). Penelitian Tindakan Kelas. Jakarta: Bumi Aksara.

Huda, M. (2015). Model-Model Pe-ngajaran dan Pembelajaran. Yogyakarta: Pustaka

Shoimin, A. (2014). 68 Model Pembelajaran Inovatif dalam Kurikulum 213. Yogyakarta: Ar-Ruzz Media.

Susanto, A. (2016). Teori Belajar \& Pembelajaran di Sekolah Dasar. Jakarta: Prenadamedia Grup.

Sutirto. (2016). Peningkatan Kemampuan Membaca Melalui Penerapan Metode Cooperative Integrated Reading Composition (CIRC). Jurnal Penelitian Pendidikan Indonesia (JPPI), 1(4): 58-65.

Tarigan, H.G. (2008). Membaca Sebagai Suatu Keterampilan Berbahasa. Bandung: Angkasa Bandung. 